\title{
DOI https://doi.org/10.30525/978-9934-26-121-3-13
}

\section{ДЕРЖАВНО-УПРАВЛІНСЬКІ ВАЖЕЛІ ЗАБЕЗПЕЧЕННЯ ВИРІВНЮВАННЯ СОЦІАЛЬНОГО РОЗВИТКУ РЕГІОНІВ УКРАЇНИ: ПРОБЛЕМИ ЗАСТОСУВАННЯ}

\author{
Мельничук Л. М. \\ доктор наук з державного управління, \\ доцент кафедри публічного управління та адміністрування \\ Навчально-наукового інституту неперервної освіти \\ Національного авіаційного університету \\ м. Київ, Украӥна
}

Успішність політики соціального розвитку регіонів залежить від цілісності системи та ефективності засобів впливу на соціальні процеси регіонального розвитку в межах кожної галузевої чи функціональної політики, поєднання та/чи узгодження застосування інструментів впливу на соціальні процеси різних сфер політики. Водночас рівність та рівномірність розвитку досягається завдяки дієвості та ефективності системи державно-управлінських засобів забезпечення вирівнювання соціального розвитку регіонів. Проблеми державно-управлінського впливу на соціальні процеси регіональних систем широко відображені як у дослідженнях 3 питань регіональної економіки та політики, так і в науковому доробку фахівців у сфері соціогуманітарної політики. Проте зміст перших зводиться до економічних аспектів розвитку, переважно без виділення соціальної специфіки, зміст других - до розвитку людського потенціалу чи рівня життя населення.

Водночас, результати досліджень автора засвідчують, що досягнення благополуччя усіх громадян незалежно від їх територіальної приналежності залежить від рівного доступу населення до реалізації соціальних прав, що, своєю чергою, визначається змістом принципу соціально-правової рівності за ознакою місця проживання та зумовлює потребу у визначенні його змісту, способів та проблем забезпечення в Україні [1, с. 45-46].

Грунтуючись на результатах досліджень у галузі права, зокрема [6], варто відмітити, що незважаючи на відсутність єдиного підходу до трактування цього принципу, найбільшого поширення набуло його розуміння як рівних за змістом, обсягом та можливостями реалізації прав людини і громадянина, що відповідає європейській практиці та міжнародним стандартам забезпечення прав людини. На таких же 
засадах принцип рівності визначено в Конституції України (стаття 24). I хоча закріплення на рівні Основного закону рівності прав і свобод людини та громадянина $є$ важливою гарантією його здійснення, однак не гарантує його автоматичної реалізації. Саме тому виникає нагальна потреба у виробленні та ефективному впровадженні механізму забезпечення принципу рівності соціальних прав як одного із ключових завдань соціальної політики держави. До того ж, впровадження соціально-правової рівності за територіальною ознакою надаватиме соціальній політиці територіального спрямування, просторової орієнтації, що актуалізується впровадженням низки політичних реформ, передусім, децентралізації влади.

Виходячи зі змісту принципу рівності, правомірно стверджувати, що здійснення соціальних прав громадян на засадах рівності за територіальною ознакою передбачає позитивні дії держави, конкретні іiі обов'язки, які виражаються у сукупності зафіксованих у законі різноманітних гарантій, що позначають умови й засоби, які підвищують вірогідність здійснення, практичну реалізацію соціальних прав громадян, попередження та/чи усунення можливих перешкод для їх повного або належного здійснення. Тобто діяльність держави має здійснюватися у трьох взаємопов'язаних напрямах, які й складають цілісний механізм забезпечення рівності соціальних прав (реалізації; охорони; захисту), кожний з яких має містити сукупність способів, засобів і методів, спрямованих на ефективне втілення в життя рівних за змістом, обсягом та можливостями реалізації соціальних прав. При цьому слід враховувати, що принцип рівності соціальних прав за територіальною ознакою проявляється не лише на рівні окремої особи, а й угрупувань людей, об'єднаних місцем їхнього проживання. 3 урахуванням зазначеного аналіз законодавства дозволяє визначити певну сукупність інструментів, спрямованих на забезпечення рівного доступу громадян до соціальних прав на будь-якій території країни, серед яких:

- правові гарантії, соціальні стандарти та соціальні нормативи, система послуг соціального спрямування як способи реалізації принципу рівності;

- заборона дискримінації, державний нагляд та контроль, моніторинг якості послуг, що покликані забезпечити охорону принципу рівності;

- встановлення відповідальності та інституційні гарантії (суди, інститути омбудсменів), які виступають засобами захисту принципу рівності соціальних прав громадян. 
При цьому аналіз національного законодавства та практичного впровадження його положень засвідчує низку проблем забезпечення принципу соціально-правової рівності за територіальною ознакою.

1. Фрагментарний характер встановлення гарантій рівності сочіальних прав громадян за ознакою місия їх проживання. Так, соціальним законодавством гарантії рівності за ознакою місця проживання закріплені лише у сфері зайнятості, освіти та, певним чином, охорони здоров'я [1, с. 206-207]. Це зумовлює панування переважно людиноорієнтованого підходу у процесі реалізації соціальної політики держави без врахування особливостей регіонів, а також призводить до викривлень у визначенні соціальних пріоритетів регіональної політики [5].

2. Відсутність дійових засобів використання внутрішнього потенціалу самих регіонів у прочесі практичного втілення соціальних стандартів та сочіальних гарантій. Незважаючи на зростання доходів місцевих бюджетів [2, с.8], нереалізованим залишається право місцевих органів влади передбачати додаткові соціальні гарантії при розробці та реалізації місцевих соціально-економічних програм, а також затверджувати регіональний прожитковий мінімум для оцінки рівня життя в регіоні, розроблення та реалізації регіональних соціальних програм, визначення права на призначення певних видів соціальної допомоги [4]. Відповідно за таких умов унеможливлюється створення необхідного середовища для реалізації соціальних прав громадян певного регіону.

3. Неефективність інвестищійної практики розвитку соціальної інфраструктури. Державний фонд регіонального розвитку, який на даний час слугує ключовим державним інвестиційним інструментом, не став дієвим фінансовим важелем розвитку соціальної сфери на регіональному рівні. Практика його застосування демонструє, що переважна більшість інвестиційних проектів і програм спрямована на покращення умов для надання послуг, i лише незначна їх кількість передбачає розширення просторового та фізичного доступу населення до них [3]. Крім того, фінансова підтримка надається більшою мірою освітнім і медичним закладам. Увагою органів влади оминаються інші заклади соціального спрямування, діяльність яких відіграє важливу роль у забезпеченні соціальних прав громадян, отже й в цілому благополуччя населення певної території.

4. Відсутність у процесі моніторингової діяльності оцінки регіональних особливостей забезпечення сочіальних прав громадян та впливу функціональних сфер політики на просторовий розвиток, що позбавляє можливостей вироблення чітких стратегічних пріоритетів 
модернізації державного управління соціальними процесами у територіальній проекції. На сьогодні проводиться лише моніторинг та оцінювання ефективності програм соціальної підтримки населення (постанова Кабінету Міністрів України від 20.06.2012 № 554), серед основних завдань якого проведення аналізу основних показників виконання таких програм; оцінювання їх ефективності та впливу на бідність, тобто на проблемну ситуацію, проте без врахування територіального аспекту. Такі обмеження не компенсуються і в межах здійснення регіональної політики, до функцій якої належить оцінювання впливу функціональних сфер політики на просторовий розвиток [5]. Система відстеження результатів діяльності держави не відображає територіального впливу соціальної політики та її окремих напрямів на процеси соціальних змін [3].

5. Формальний характер системи захисту соціально-правової рівності у регіональному вимірі. За відсутності чітких гарантій рівності система відповідальності має формальний характер. Не сприяє вирішенню цього питання й існування достатньо сформованої системи інституційного захисту рівності. Вкрай проблематичним в умовах недосконалості судової системи є захист навіть прав конкретних осіб за конкретною ознакою, не кажучи про забезпечення рівності прав мешканців однієї території по відношенню до іншої.

Таким чином, в Україні відсутня цілісна, ефективна система важелів державно-управлінського впливу на соціальні процеси регіонального рівня, яка б забезпечила рівний доступ населення до соціальних прав незалежно від території проживання, отже й соціальне вирівнювання регіонального розвитку.

\section{Література:}

1. Мельничук Л. М. Державне управління соціальним розвитком регіонів України: реалії та перспективи. Монографія. Луцьк, Терен, 2018. $440 \mathrm{c}$.

2. Новікова О.Ф., Логачова Л. М. Особливості фінансування соціальної інфраструктури в процесі бюджетної децентралізації. Економічний вісник Донбасу. 2017. № 1. С. 4-12.

3. Офіційний сайт Міністерства розвитку громад та територій України URL: http://www.minregion.gov.ua (дата звернення: 03.07.2021)

4. Про державні соціальні стандарти та державні соціальні гарантії : Закон України від 05.10.2000 № 2017-III із змінами / Верховна Рада України. URL: http://zakon3.rada.gov.ua/laws/show/2017-14 (дата звернення: 01.07.2021) 
5. Про засади державної регіональної політики: Закон України від 05.02.2015 № 156-VIII / Верховна Рада України. URL: http://zakon5.rada. gov.ua/laws/ main/156-19 (дата звернення: 06.07.2021)

6. Чепульченко Т. О. Принцип рівності у праві: теоретикоприкладний аспект. Держава і право. Серія : Юридичні науки. 2019. Вип. 83. С. 24-34.

\title{
DOI https://doi.org/10.30525/978-9934-26-121-3-14
}

\section{ОСНОВНІ НАПРЯМИ УДОСКОНАЛЕННЯ ІНФОРМАЦІЙНО- КОМУНІКАТИВНОГО МЕХАНІЗМУ ДЕРЖАВНОГО РЕГУЛЮВАННЯ ПІДПРИСМНИЦТВА}

\begin{abstract}
Статівка Н. В.
доктор наук з державного управління, професор, завідувач кафедри управління персоналом та економіки праці Харківського регіонального інституту держсавного управління Національної академії державного управління при Президентові Украӥни
\end{abstract}

\section{Бублій М. П.}

кандидат наук з державного управління, доцент, доцент кафедри управління персоналом та економіки праці, Харківського регіонального інституту державного управління Національної академї̈ державного управління при Президентові України м. Харків, Україна

Роль інформаційно-комунікаційних технологій виражається в новому типі економічного зростання, кардинального оновлення базових технологій, появі на ринку нової або модифікованої техніки, у виробництві принципово нових продуктів та послуг, у прискореному розвитку нематеріальної сфери. Це неможливо досягти без підвищеної уваги до вдосконалення людського капіталу, науки, новітніх знань і т. д. В силу цих якісних перетворень створюється база так званої «нової економіки» або «економіки знань», де все зростаючу роль, в тому числі в матеріальному виробництві, починає грати сфера інтелектуальних послуг [1, с. 12]. Саме вона за допомогою інформаційно-комунікаційних технологій визначає не тільки прогресивність i конкурентоспроможність продукції, але і потенціал всієї національної економіки 